\title{
Egg Preservation
}

National Cancer Institute

\section{Source}

National Cancer Institute. Egg Preservation. NCI Thesaurus. Code C18759.

Methods for preserving egg cells such as oocyte cryopreservation in liquid nitrogen. 